\title{
COMMENTS
}

\section{UNRAVELING THE CONUNDRUM OF THE LAW OF PERSONAL JURISDICTION: A COMMENT ON ASAHI METAL INDUSTRY CO. V. SUPERIOR COURT OF CALIFORNIA}

\author{
EARL M. MALTZ*
}

Try as it might, the Supreme Court seems unable to satisfy the critics of its approach to personal jurisdiction problems. Despite the Court's repeated efforts over the past decade to clarify the due process constramts upon the exercise of personal jurisdiction by the states, ${ }^{1}$ each decision brings only new criticism from the academy. Some commentators simply disagree with the substantive value judgments embodied im the Court's approach. Others suggest that the Court is acting entirely irrational. ${ }^{2}$ Those taking the latter position have nothing but conteinpt for the existing doctrinal framework; these critics use phrases such as "abstractions [decoupled from] any conceivable value,"3 "incoherent by

* Professor of Law, Rutgers (Camden); J.D., 1975, Harvard. The author gratefully acknowledges the assistance of Lea Brilmayer, who read and commented upon a draft of this article.

1. Since 1977, the Supreme Court has decided eleven major personal jurisdiction cases: Asahi Metal Indus. Co. v. Superior Ct., 107 S. Ct. 1026 (1987); Phillips Petroleum Co. v. Shutts, 472 U.S. 797 (1985); Burger King Corp. v. Rudzewicz, 471 U.S. 462 (1985); Hehicopteros Nacionales de Colombia, S.A. v. Hall, 466 U.S. 408 (1984) (Helicol); Calder v. Jones, 465 U.S. 783 (1984); Keeton v. Hustler Magazine, Inc., 465 U.S. 770 (1984); Insurance Corp. of Ireland v. Campagnie des Bauxites de Guinee, 456 U.S. 694 (1982); Rush v. Savchuk, 444 U.S. 320 (1980); World-Wide Volkswagen Corp. v. Woodson, 444 U.S. 286 (1980); Kulko v. Superior Court, 436 U.S. 84 (1978); Shaffer v. Heitner, 433 U.S. 186 (1977).

2. See e.g., McDougal, Judicial Jurisdiction: From a Contacts to an Interest Analysis, 35 VAND. L. Rev. 1, 8-13 (1982) (criticizing Court's minimum contacts test as based on vague or inadequate notions of state boundaries); Weinberg, The Helicopter Case and the Jurisprudence of Jurisdiction, 58 S. CAL. L. REV. 913, 919 (1985) (discussing Court's separation of minimum contacts concept from due process concerns of convenience and fairness to plaintiffs); Weintraub, Due Process Limitations on the Personal Jurisdiction of State Courts: Time for Change, 63 OR. L. REv. 485, 512 (1984) (correctly anticipating and criticizing Court's refusal in Helicol to extend general jurisdiction based on defendant's "continuous and substantial" contacts with fornm state).

3. Weinberg, supra note 2, at 919. 
its own terms,"4 and inconsistent with "modern social realities"5 to characterize the Court's personal jurisdiction analysis.

The Supreme Court's recent decision in Asahi Metal Industry Co. v. Superior Court of California ${ }^{6}$ is sure to add fuel to the fire. Asahi not only raises issues critical to the law of personal jurisdiction, but also adds a twist: for the first time, the Court explicitly faced the question of whether the assertion of specific jurisdiction ${ }^{7}$ over aliens was subject to a different test than a similar assertion of specific jurisdiction over nonresident American citizens. ${ }^{8}$ If past experience is any guide, the Court's resolution of these issues should generate a flood of new scholarly criticism of the judicial analysis.

This comment takes a somewhat different view. Rejecting the claim that the Supreme Court's approach to personal jurisdiction cases is incoherent, I use Asahi as a paradigm to argue that the decisional pattern of personal jurisdiction cases is the product of the interaction of a number of perfectly understandable conceptions of fairness held by individual Justices. This comment briefly outlines the state of personal jurisdiction law prior to $A s a h i,{ }^{9}$ and then discusses the various opinions issued in Asahi and explores the conceptions of fairness underlying the approaches of different Justices. ${ }^{10}$

\section{Prior Supreme Court LaW}

As virtually every law student knows, the nodern law of personal jurisdiction began with the case of International Shoe Co. v. Washington. ${ }^{11}$ International Shoe discarded the legal fiction of "presence" as the test for asserting jurisdiction and established the rule that a state inay assert jurisdiction only over those defendants who "have certain minimum contacts with [the foruin state] such that the inaintenance of the suit does not offend 'traditional notions of fair play and substantial justice." "12

The International Shoe test was elaborated and refined during the Warren Court era, in decisions such as McGee v. International Life In-

4. Stein, Styles of Argument and Interstate Federalism in the Law of Personal Jurisdiction, 65 TEX. L. REv. 689, 734 (1987) (arguing that Court's purposeful availment rationale is incoherent and "derived from a vision of sovereign authority that is too limited and too dependent on consent").

5. Weintraub, supra note 2 , at 512 .

6. 107 S. Ct. 1026 (1987).

7. See infra note 52 .

8. $107 \mathrm{~S}$. Ct. at 1031-34.

9. See infra notes 11-53 and accompanying text.

10. See infra notes 54-118 and accompanying text.

11. 326 U.S. 310 (1945).

12. Id. at 316 (quoting Milliken v. Meyer, 311 U.S. 457, 463 (1940)). 
surance Co. ${ }^{13}$ and Hanson v. Denckla. ${ }^{14}$ In these decisions, the Court's "minimum contacts" analysis increasingly focused on purposeful acts on the part of the defendant that would justify the exercise of jurisdiction. In $M c G e e$, for example, a unanimous Court found that the defendant's sole contact with the forum state of California-the solicitation of a single insurance policy from a Cahifornia resident-was sufficient to satisfy the due process requirement of International Shoe. ${ }^{15}$

Hanson involved a law suit over the corpus of a trust established in Delaware by a settlor who later became domiciled in Florida. ${ }^{16}$ Although prior to her death the settlor had conducted substantial trustrelated business in Florida, ${ }^{17}$ a closely divided Court nonetheless held that the estate's trustee, a Delaware bank, lacked the requisite minimum contacts that would have enabled Florida to exercise jurisdiction in the dispute. ${ }^{18}$ Neither the fact that the settlor and most of her beneficiaries and appointees were doimiciled in Florida nor the fact that the unilateral exercise of the appointment power by the settlor occurred in the forum sufficed to create jurisdiction over the trustee. Instead, the majority ruled that for jurisdiction to lie "there [must] be some act by which the defendant purposefully avails itself of the privilege of conducting activities within the forum State, thus invoking the benefits and protections of its laws." 19

Hanson estabhished that satisfaction of the minimum contacts test will largely depend on the existence of some purposeful act or acts by the defendant sufficient to create the expectation that his actions will bring

13. 355 U.S. 220 (1957).
14. 357 U.S. 235 (1958).

15. 355 U.S. at 222-23. Although the Court focused on the volitional nature of the defendant's contacts with the forum state ("[i]t is sufficient for purposes of due process that the suit was based on a contract which had substantial connection with that State"), the Court also noted the interests of the forum state ("California has a manifest interest in providing effective means of redress for its residents when their insurers refuse to pay claims") and the resident plaintiffs (" $[w]$ hen claims were small or moderate individual claimants frequently could not afford the cost of bringing an action in a foreign forum") in the minimum contacts analysis. Id. at 223.

16. 357 U.S. at 238.

17. Id. at 239. The settlor exercised her power of appointment as to the remainder of the trust while a resident of Florida. Although these appointments significantly affected the distribution of the settlor's trust, the Court held that this unilateral action did not suffice to "give Florida a substantial connection with the contract on which this suit is based. It is the validity of the trust agreement, not the appointment, that is at issue here." Id. at 253 (footnote omitted).

18. Id. at 251. The Court pointed out that the Delaware trustee did not solicit, conduct business, or maintain offices in Florida. Unlike McGee, the cause of action did not arise out of any act consummated in the forum state, but instead involved an agreement unconnected with Florida at the time it was signed. $I d$. at 251-52.

19. Id. at 253 (emphasis added). 
him within the forum state's jurisdiction. ${ }^{20}$ Significantly, the Hanson majority rejected the dissenters' suggestion that the minimum contacts test should focus on the interest of the forum state in the underlying transaction, as well as principles of foruin non conveniens and choice of law. ${ }^{21}$ The state, concluded the inajority, "does not acquire ... jurisdiction by being the 'center of gravity' of the controversy, or the most convenient location for litigation. The issue is personal jurisdiction, not choice of law."22

In the post-Warren era, purposeful availment analysis has come to dominate the Court's approach to personal jurisdiction probleins. Prior to Asahi, the parameters of the doctrine in the specific personal jurisdiction context were largely defined by three cases: World-Wide Volkswagen Corp. v. Woodson, ${ }^{23}$ Keeton v. Hustler Magazine, Inc. ${ }^{24}$ and Burger King Corp. v. Rudzewicz. ${ }^{25}$

In World-Wide Volkswagen, two New York residents brought a products liabihty suit in Oklahoma state court against nuinerous defendants, including a New York auto retailer who sold the plaintiffs an allegedly defective car. The suit arose following an autoinobile collision on an Oklahoma highway while plaintiffs were en route to their new home in Arizona. ${ }^{26}$

Plaintiffs based their jurisdictional arguinent on the theory of actual foreseeability.27 Because of the nature of the highly inobile product, plaintiffs argued, the defendants should have foreseen the possibility that it would be used in another state and cause injury there. Notwithstanding the fact that the relevant defendants had no other contacts with the forum state, ${ }^{28}$ plaintiffs contended that the assumption of jurisdiction was constitutionally permissible. ${ }^{29}$

Justice White, speaking for a six-member inajority, rejected the plaintiffs' actual foreseeability argument. ${ }^{30} \mathrm{He}$ asserted that although

20. One commentator explains that the focus on the interests of defendants in personal jurisdiction cases "rests on the advantages that a plaintiff typically enjoys in selecting among several forums and on the proposition that, other things being equal, burdens that must rest on either the challenger or the challenged are to be borne by him who seeks to change the status quo." Von Mehren, Adjudicatory Jurisdiction: General Theories Compared and Evaluated, 63 B.U.L. REv. 279, 321-22 (1983).

21. See 357 U.S. at 258-59 (Black, J., dissenting).

22. Id. at 254 .

23. 444 U.S. 286 (1980).

24. 465 U.S. 770 (1984).

25. 471 U.S. 462 (1985).

26. 444 U.S. at 288.

27. Id. at 295.

28. Id. at 289.

29. Id. at 295.

30. Id. at 295-96. 
foreseeability is [not] wholly irrelevant ... the foreseeability that is critical to due process analysis is not the mere likelihood that a product will find its way into the forum State. Rather, it is that the defendant's conduct and connection with the forum State are such that he should reasonably anticipate being haled into court there. ${ }^{31}$

The Court contended that absent some "purposeful availment" by the defendant corporation of the "privilege[s] of conducting activities within the forum State," "32 due process does not permit the assertion of personal jurisdiction over nonresident defendants based on the "unilateral activity" of plamtiffs over which defendants exercise no control. Finding a "total absence of those affiliating circumstances that are a necessary predicate to any exercise of state-court jurisdiction," Justice White concluded that the mimimum contacts requirement had not been met. ${ }^{33}$

Keeton v. Hustler Magazine, Inc. ${ }^{34}$ provides a useful counterpoint to World-Wide Volkswagen. Keeton was a hibel action brought in New Hampshire against Hustler Magazine, an Ohio corporation. Hustler Magazine's principal place of business was in California; its only connection with New Hampshire was that a small proportion of its magazines (some of which contained the allegedly libelous statements) were sold in that state. The plaintiff was a New York resident; her only connection with the forum was that her name appeared on the masthead of several magazines distributed in New Hampshire. ${ }^{35}$ The Court unamimously held that the fourteentli amendment did not prevent the New Hampshire courts from asserting jurisdiction over the defendant: "Where, as in this case, [the defendant] has continuously and dehberately exploited the New Hampshire market, it must reasonably anticipate bemg lialed into court there in a hibel action based on the contents of its magazine."36 The Court reached this conclusion notwithstanding the fact that the plaintiff was not a resident of New Hampshire; only a small portion of the damages were suffered there; and the forum was almost certamly cliosen to take advantage of an unusually long statute of liimitations.

31. Id. at 297. White noted a two-fold purpose behind the minimum contacts test: to protect defendants and to ensure that states did not encroach on each other's sovereign interests. The latter rationale was abandoned in Insurance Corp. of Ireland, Ltd. v. Campagnie des Bauxites de Guinee, 456 U.S. 694, 702 n.10 (1982). See infra notes 112-14 and accompanying text.

32. 444 U.S. at 297 (quoting Hanson v. Denckla, 357 U.S. 235, 253 (1958)).

33. Id. at 295. See also Kulko v. Superior Court, 436 U.S. 84 (1978) (no personal jurisdiction in domestic relations suit when father, by merely sending daughter to California to visit estranged wife, neither showed intent to obtain or expectation to receive corresponding state benefit). See generally Note, The Long-Arm Reach of the Courts Under the Effect Test After Kulko v. Superior Court, 65 VA. L. REV. 175, 181-83 (1979).

34. 465 U.S. 770 (1984).

35. Id. at 772 .

36. Id. at 781 . 
Thus, once again, purposeful availment was clearly the central factor in the Court's analysis.

The same theme dominated the Court's analysis in Burger King $v$. Rudzewicz. ${ }^{37}$ The defendant in Burger King, a Michigan resident, had entered into a franchise agreement with a Florida corporation. The agreement contemplated a contmuing relationship between the parties and required payments to be made in Miami, Florida. Throughout the negotiations, however, the defendant had remamed in Michigan; indeed, he had never physically been in the state of Florida. ${ }^{38}$ Nonetheless, the Court held that in a lawsuit over an alleged breach of the franchising agreeinent, the Florida courts could constitutionally assert personal jurisdiction over the defendant. ${ }^{39}$ The majority held that

where the contacts [with the forum] proximately result from actions by the defendant himself that create a "substantial connection" with the forum State ... he manifestly has availed himself of the privilege of conducting business there, and because his activities are shielded by "the benefits and protections" of the forum's laws it is presumptively not unreasonable to require him to submit to the burdens of litigation in that forum as well.40

Taken together, World-Wide Volkswagen, Keeton and Burger King clearly establish the primacy of the concept of purposeful availment in personal jurisdiction analysis. In World-Wide Volkswagen, jurisdiction was barred because the defendant's only contact with the forum state was created by the " 'unilateral activity of those who claim some relationship with a nonresident defendant." "41 In contrast, when the defendants created the relationship with the forum state-as in Keeton and Burger King - the assertion of jurisdiction was held constitutional. ${ }^{42}$ While leaving some cases at the inargins unclear, these principles provide clear guidance in inost situations involving domestic defendants. None of the three decisions, however, addressed the problem of jurisdiction over aliens.

Several coinmentators have suggested that different standards should be applied when dealing with ahen defendants. ${ }^{43}$ Prior to Asahi,

37. 471 U.S. 462 (1985).

38. Id. at $465-68,476,479$.

39. Id, at 478 .

40. Id. at $475-76$ (emphasis in original).

41. 444 U.S. 286, 298 (1980) (quoting Hanson v. Denckla, 357 U.S. 235, 253 (1958)).

42. Keeton, 465 U.S. at 781; Burger King, 471 U.S. at $479-80$.

43. Professor Hay, for example, contends that states should be allowed to aggregate the contacts of an alien defendant with the United States as a whole rather than being forced to rely only on the contacts with the forum state itself. Hay, Judicial Jurisdiction over Foreign-Country Corporate Defendants-Comments on Recent Case Law, 63 OR. L. REv. 431, 433-35 (1984). Thus, he would allow the assertion of jurisdiction over aliens in situations in which an analogous domestic party 
the Supreme Court never explicitly addressed the question. ${ }^{44}$ The issue had, however, been potentially relevant in two earhier decisions-Perkins v. Benguet Consolidated Mining Co. ${ }^{45}$ and Helicopteros Nacionales de Colombia, S.A. v. Hall (Helicol).$^{46}$

The defendant in Perkins was a corporation operating under Filipino charter. ${ }^{47}$ While the Japanese occupied the Philippine Islands during World War II, the corporation carried on "a continuous and systematic, but limited, part of its general business" in the state of Ohio. The Ohio activities of the corporation included directors' ineetings, busi-

would plainly not be amenable to suit. Focusing on considerations of fairness to the plaintiff, Professor Weinberg would also allow more expansive jurisdiction over aliens in cases similar to Helicol. Weinberg, supra note 2, at 931-34, 945-46. In contrast, Professors von Mehren and Trautman argue that, because of the potentially greater difficulties in enforcing judgments outside the country, jurisdiction over aliens should face inore stringent judicial scrutiny. See von Mehren \& Trautman, Jurisdiction to Adjudicate: A Suggested Analysis, 79 HARv. L. REv. 1121, 1127-28 (1966). Finally, Professor Gary Boru takes a middle position, elnbracing the concept of national contacts but contending that the reach of state court jurisdiction should be limited to avoid creating tensions in foreign affairs. Born, Reflections on Judicial Jurisdiction in International Cases, 17 GA. J. OF INT'L AND CoMP. L. 1, 27-44 (1987). See generally Brilmayer, The Extraterritorial Application of American Law: A Methodological and Constitutional Appraisal, LAW AND CoNTEMP. ProBs., Suminer, 1987 (forthcoming) (suggesting that concerns of federalism should influence jurisdictional analysis in international cases).

44. Before $A s a h i$, lower courts were deeply divided over the appropriate personal jurisdiction standard for aliens. See Born, supra notc 43, at 6-10 (listing cases). Professor Born's review of the pre-Asahi case law reveals a three-way split among the lower state and federal courts in state law cases: while a majority of courts applied the identical standard to resolve personal jurisdiction challenges by foreigners and by United States citizens, a minority of courts required "closer contacts with the foruin state than would be necessary for jurisdiction over a United States defendant." Id. at 8 (emphasis in original). A minority of courts required "less close contacts with the forum State from foreign defendants than froin doinestic persons." Id. (emphasis in original). Sinnilarly, "[t]he treatment of judicial jurisdiction by lower courts in federal question cases also is marked by confusion." Id. at 9. While most courts "analyze questions of in personam jurisdiction over alien defendants by examining the relationship of the defendant, the litigation and the forum under traditional International Shoe principles," Superior Coal Co. v. Ruhrkohle, A.G., 83 F.R.D. 414, 419 (E.D. Pa. 1979), cited in Born, supra note 43, at 9, other courts adopt an "aggregate contacts" or "national contacts" test that looks to "the aggregate presence of the defendants' apparatus in the United States as a whole," Engineered Sports Prods. v. Brunswick Corp., 362 F. Supp. 722, 728 (D. Utah 1973), quoted in Born, supra note 43, at 10 .

Asahi does not definitively resolve the divisions ainong the lower federal courts as to the appropriate personal jurisdiction standard for foreign defendants. In fact, the Court declines "to determine whether Congress could, consistent with the Due Process Clause of the Fifth Amendment, authorize federal court personal jurisdiction over alien defendants based on the aggregate of national contacts, rather than on the contacts between the defendant and the State in which the federal court sits." 107 S. Ct. 1026, 1033 n.* (1987). Nonetheless, Asahi strongly suggests that, whenever "the Federal interest in ... foreign relations policies" is implicated by the assertion of jurisdiction over a foreign defendant, courts should proceed with greater care and caution in deciding whether to assert jurisdiction, $i d$. at 1035 . See infra notes $100-18$ and accompanying text.

45. 342 U.S. 437 (1952).

46. 466 U.S. 408 (1984).

47. 342 U.S. at 439. 
ness correspondence, banking, stock transfers, payment of salaries and purchasing of machinery for miming operations. ${ }^{48}$ The Supreme Court held that the due process clause neither compelled nor prevented the Ohio courts from asserting postwar jurisdiction over the corporation in an action that did not relate to or arise out of its Ohio activities. ${ }^{49}$

Helicol involved a Texas tort action arising from a hehicopter crash in Peru. The defendant, Helicol, was a Colombian corporation that had contracted to provide helicopter transportation for a Peruvian consortium that in turn was the alter ego of a joint venture lieadquartered in Houston. The defendant had sent its chief executive officer to Houston to negotiate the transportation contract; accepted checks drawn on a Texas bank; purchased helicopters, equipment and training sessions from a Texas manufacturer; and sent personnel to that manufacturer's facilities for training. ${ }^{50}$ The defendant had no other contacts with the forum state. Treating the issue solely as one of general jurisdiction, the Supreme Court held that the Texas courts had no jurisdiction over the defendant. ${ }^{51}$

Neither Perkins nor Helicol suggest that alien defendants, at least for jurisdictional purposes, should be treated differently than American citizens or corporations. Botli cases, lowever, dealt only with issues of general jurisdiction-jurisdiction based on claims unrelated to the defendant's contact with the forum. ${ }^{52}$ Neitlier addressed the standards to be applied to assertions of specific jurisdiction-jurisdiction over actions arising from or related to the defendant's connections to the forum state. A defendant subject to general jurisdiction would in any event have substantial connections with the forum; under these circumstances the sig-

48. Id. at 438,445 .

49. Id. at $446,448-49$. The Court remanded the case to determine "whether, as a matter of federal due process, the business done in Ohio by the respondent mining coinpany was sufficiently substantial and of such a nature as to permit Ohio to entertain a cause of action against a foreign corporation, where the cause of action arose from activities entirely distinct from its activities in Ohio." Id. at 447 (emphasis in original).

50. 466 U.S. $408,409-12$ (1984).

51. Id. at $416,418-19$.

52. See id. at 414 nn.8-9; Perkins, 342 U.S. at 446. A court has general jurisdiction over a defendant if it would have jurisdiction over any claim against that defendant. The exercise of general jurisdiction typically requires that the defendant have "continuous and systematic general business contacts" with the forum state. Helicol, 466 U.S. at 416. An assertion of specific jurisdiction, in contrast, rests only on the claim that the court has jurisdiction over the defendant in the single case before it. Specific jurisdiction inevitably involves adjudication of a controversy directly relating to the defendant's contact with the foruni. Id. at n.8. This terminology was first employed in von Mehren \& Trautman, supra note 43 , at $1136,1144-45$.

The respondent's brief in the Helicol proceeding was somewhat cryptic, failing to distinguish clearly between the two jurisdictional theories. The Court, however, chose to view the brief as based only on a theory of general jurisdiction. Helicol, 466 U.S. at 415 \& n.10. Nevertheless, the Court arguably should also have addressed the issue of specific jurisdiction. 
nificance of any potential distinction between aliens and American citizens would be reduced. Thus, it is not surprising that it was in a specific jurisdiction case-Asahi-that the defendant's alien status emerged for the first time as an important factor in the Court's personal jurisdiction analysis. ${ }^{53}$

\section{ASAHI METAL INDUSTRY CO. V. SUPERIOR COURT OF CALIFORNIA}

Asahi involved a products hability action arising from a motorcycle accident in California. The cause of the accident was a rear tire blowout. The rider of the motorcycle sued, among others, Cheng Shin Rubber Industrial Co., Ltd., the Taiwanese inanufacturer that had produced the motorcycle inner tube and made twenty percent of its total Umited States sales in California. ${ }^{54}$ Cheng Shin in turn filed a cross-complaint seeking indemnity from Asalii, the nuanufacturer of the tube's valve assembly. ${ }^{55}$ Asahi, a Japanese corporation, sold 1,350,000 valve assemblies to Cheng Shin in the period from 1978 to 1982; in addition, Asahi valve assemblies were incorporated into the tubes of numerous other manufacturers selling their product in California. ${ }^{56}$ Asahi itself, however, had no offices, property or agents in California and neither solicited business nor made any direct sales in that state.

The Suprenie Court unanimously held that the due process clause prevented California fron 1 asserting jurisdiction over Asahi. ${ }^{57}$ Eight Justices agreed that, regardless of whether Asahi had "purposefully availed" itself of the benefits and burdens of doing busimess im the foruin state, "the facts of [the] case [did] not establish minimuni contacts such that the exercise of personal jurisdiction [would be] consistent with fair play and substantial justice."58 The Court was deeply divided, however, on the question of whether the Japanese manufacturer could be said to have purposefully availed itself of the privilege of doing business in California.

Justice O'Connor, Chief Justice Rehnquist, and Justices Powell and Scalia (the O'Connor Group) argued that Asahi's position was analogous

53. 107 S. Ct. 1026, 1034-35 (1987).

54. Id. at 1029-30.

55. Id.

56. Although the Court's factual statement does not indicate what percentage of all Cheng Shin tires sold in the United States contain Asahi valve assemblies, or whether Cheng Shin used only Asahi valve assemblies, it does appear that Asahi's valve assembly sales to Cheng Shin constituted a fairly minor portion of its total business: sales to Cheng Shin accounted for 1.24 percent of Asahi's income in 1981, and 0.44 percent in 1982. Id. at 1030. It is not clear, however, what percentage of Asahi's valve assembly business was directed at Cheng Shin.

57. Id. at 1033-35.

58. Id. at 1035. Justice Scalia apparently would have ended the inquiry once satisfied that purposeful availment was not present. 
to that of the defendant in World-Wide Volkswagen. ${ }^{59}$ The O'Connor Group contended that "awareness that the stream of commerce may or will sweep the product into the forum State does not convert the mere act of placing the product into the stream into an act purposefully directed toward the forum State." 60 Instead, "[t]he 'substantial connection" between the defendant and the forum State necessary for a finding of minimum contacts must come about by an action of the defendant purposefully directed toward the forum State." 61 Because Cheng Shin, and not Asahi itself, had made the choice to send Asahi's products to California, there was no purposeful availment and the assertion of jurisdiction was unconstitutional. The O'Connor Group, however, did not address the question of whether purposeful availment alone would always provide a sufficient predicate to subject a defendant to jurisdiction.

In contrast, Justices Brennan, White, Marshall and Blackmun (the Brennan Group) argued that the purposeful availment requirement is satisfied once a inanufacturer inserts its product into the stream of commerce with knowledge that the product will eventually be used in the forum state. ${ }^{62}$ Justice Stevens would have dechined to reach the purposeful availment issue; instead, he would have adopted an intermediate approach, basing the constitutional analysis on "the volume, the value and the hazardous character of the components" at issue. ${ }^{63}$ Stevens suggested that "[i]n most circurnstances" he would have found jurisdiction

59. Id. at 1031-33 (opinion of O'Connor, J.). The O'Connor Group maintained that Asahi should not be held accountable in a California state court for the consequences flowing from Cheng Shin's unilateral act of introducing Asahi products.

60. Id. at 1033 .

61. Id. (quoting Burger King, 471 U.S. 462, 475 (1985) (emphasis in original)). Justice O'Connor noted that Asahi's awareness that its valves may have been used in Cheng Shin tire tubes sold in California would not be sufficient to satisfy her interpretation of purposeful availment. Because Asahi neither advertised, solicited business nor maintained agents or offices in California, and because it was neither responsible for nor aware of the distribution system that brought its valves to California, under O'Connor's view exercise of personal jurisdiction would exceed the limits of due process, whether or not Asahi was aware of its products' ultimate destination. Id.

62. Id. at 1035-38 (Brennan, J., concurring in part). Justice Brennan noted the distinction drawn in World-Wide Volkswagen " "between a case involving goods which reach a distant State through a chain of distribution and a case involving goods which reach the same State because a consumer ... took them there." "Id. at 1037 (citing World-Wide Volkswagen, 444 U.S. 286, 306-07 (1980) (Brennan, J., dissenting)). He argued that Asahi's mere awareness that Cheng Shin's system of distribution carried its valve assemblies into California sufficed to bring Asahi within World-Wide Volkswagen's definition of purposeful availment. Id. at 1037-38.

63. Id. at 1038 (Stevens, J., concurring in part). Justice Stevens was joined by two Justices from the Brennan Group, Justices White and Blackmun. It is not clear whether Justices White and Blackmun simultaneously adopted Stevens' intermediate approach, as well as the Brennan Group's approach, to purposeful availment, or whether their concurrence with Justice Stevens was limited to his point that the Court should have restricted its inquiry to the reasonableness of asserting jurisdiction, rather than reaching the minimum contacts question. 
over a manufacturer such as Asahi constitutionally permissible. ${ }^{64}$

Because five members of the Court-Justices Brennan, White, Marshall, Blackmun and Stevens-appear to beheve that Asahi purposely availed itself of the benefits and burdens of doing business in California, the decision not to grant the California courts jurisdiction over Asahi turned on other factors. Of paramount inportance in ascertaining these factors is the portion of Justice O'Connor's opinion supported by all the Justices except Justice Scahia. In that part of her opinion, Justice O'Connor concluded that the assertion of jurisdiction, regardless of one's view of the purposeful availment issue, would offend traditional notions of fair play and substantial justice and therefore was unconstitutional. 65 The opinion recited the familiar hitany of factors used by the Court in earher personal jurisdiction cases: "the burden on the defendant, the interests of the forum state, ... the plaintiff's interest in obtaining rehef, ... 'the mterstate judicial system's mterest in obtaining the most efficient resolution of controversies; and the shared interest of the several States in furthering fundamental substantive social policies." "66

In finding the assertion of jurisdiction improper, Justice O'Connor relied heavily on two factors derived from the international scope of the jurisdictional problem: "The umique burdens placed upon one who must defend oneself im a foreign legal system" and the potential implications for United States foreign policy. ${ }^{67}$ Slie also focused on the distance that the defendant would be forced to travel to defend itself, and the fact that the plaintiff's claim against Cheng Shin had been settled, leaving only the indemnity issue to be adjudicated. ${ }^{68}$ Justice O'Connor argued that because no California resident was a party to the cross-claim, the interest of the state in the resolution of the claim was "slight," and thus insufficient to justify the imposition of the "serious burdens" on Asahi. 69 In short, in Asahi, the Court for the first time since its adoption of the purposeful availment analysis denied jurisdiction over a defendant that had purposefully availed itself of the benefits and burdens of doing business in the forum.

\footnotetext{
64. Id.

65. Id. at 1033-35.

66. Id. at 1034 (quoting World-Wide Volkswagen, 444 U.S. at 292).

67. Id. at 1034-35.

68. Id. at 1034 .

69. Id.
} 


\section{THE LeSSONS OF ASAHI}

\section{A. The Relevance of Minimum Contacts.}

On a purely theoretical level, the treatment of the concept of minimum contacts is one of Asahi's most significant developments. Until quite recently, the Court consistently held that the existence of minimum contacts is both a necessary and sufficient condition for the constitutional assertion of jurisdictional authority. ${ }^{70}$ While the rhetoric of purposeful availment had come to dominate modern opinions, that concept seemed to be a simple gloss on the rninimum contacts test itself. ${ }^{71}$ Thus, as late as 1984, Justice Rehnquist was able to state confidently for a unaninious Court in Calder v. Jones 72 that "[t] he Due Process Clause . . p permits personal jurisdiction over a defendant in any State with which the defendant has 'certain ininimuin contacts ... such that the maintenance of the suit does not offend "traditional notions of fair play and substantial justice." "73

The first hint of a change in the role of ininimum contacts came in Justice Brennan's majority opinion in Burger King. While noting that "the constitutional touchstone remams whether the defendant purposefully established 'minimum contacts' in the forum State,"74 he also stated that "[o]nce it has been decided that a defendant purposefully established minimum contacts within the forum State, these contacts may be considered in light of other factors to determine whether the assertion of personal jurisdiction would comport with 'fair play and substantial justice." "75 The precise import of this language was not entirely clear; it seemed, however, to imply that in some circumstances the assumption of jurisdiction would be unconstitutional even if the defendant had minimum contacts with the foruin state. ${ }^{76}$

70. See, e.g., Keeton v. Hustler Magazine, Inc., 465 U.S. 770, 774 (1984) (assertion of personal jurisdiction over nonresident defendant must be predicated on minimum contacts between defendant and state); World-Wide Volkswagen Corp. v. Woodson, 444 U.S. 286, 291 (1980) ("As has long been settled, and as we rcaffirm today, a state court may exercise personal jurisdiction over a nonresident defendant only so long as there exist 'minimum contacts' between the defendant and the forum State.").

71. See, e.g., Calder v. Jones, 465 U.S. 783, 788 (1984) ("In judging minimum contacts, a court properly focuses on 'the relationship among the defendant, the forum, and the litigation.' " (quoting Shaffer v. Heitner, 433 U.S. 186, 204 (1977))).

72. 465 U.S. 783 (1984).

73. Id. at 788 (quoting International Shoe Co. v. Washington, 326 U.S. 310,316 (1945)).

74. 471 U.S. 462,474 (1985).

75. Id. at 476 (quoting International Shoe, 326 U.S. at 320).

76. Justice Brennan seems to propose a two-part analysis: once purposeful availment by the defendant is found, the Court must then inquire whether the presence of "other factors" is of sufficient importance so as to render the assertion of jurisdiction unreasonable. For example, a balancing of the relative (and sometimes competing) interests of the plaintiff, the defendant, the forum state, 
Asahi confirms this interpretation. The opinion for the Court states that " $[w]$ hen minimuin contacts have been estabhished, often the interests of the plaintiff and the forum in the exercise of jurisdiction will justify even the serious burdens placed on the alien defendant," but that the inposition of these burdens was not justified in Asahi. ${ }^{77}$ The clear iniphcation is that assertion of personal jurisdiction over Asahi would have been unconstitutional regardless of the existence of Asahi's contacts with the forum state. Justice Brennan's concurrence highlights this point: he would have denied jurisdiction despite his conclusion that "the facts found by the California Supreine Court support its finding of minimum contacts."78 Asahi thus clearly estabhishes that the existence of minimum contacts is a necessary but not sufficient condition to satisfy the constitutional requirements for personal jurisdiction. In all cases, the courts inust also test the facts against equitable notions of "fair play and substantial justice." The practical inipact of this shift in emphasis is unclear; both "inininuun contacts" and "fair play and substantial justice" are sufficiently vague to acconimodate virtually any result. Nonetheless, Asahi's change in the role of minimum contacts is an iniportant theoretical development.

the interstate judicial system, and the "several States" may "sometimes serve to establisl the reasonableness of jurisdiction upon a lesser showing of minimum contacts than would otluerwise be required." On the other liand, a defendant who lias purposefully engaged in forum activities may nonetheless "defeat jurisdiction [by] present[ing] a compelling case that the presence of some other considerations ... render[s] jurisdiction unreasonable." Burger King, 471 U.S. at 477 . While "such considerations usually may be accommodated througl means short of finding jurisdiction unconstitutional"-i.e., tlirough application of the forum's clioice-of-law rules to reduce any potential conflict of "fundamental substantive social policies" between the forum's laws and those of another state, or througl a cliange of venue to reduce "substantial inconvenience" to the defendant-they must ultimately be measured against the "minimum requirements inlierent in the concept of "fair play and substantial justice." "Id. at 477-78 (citing World-Wide Volkswagen, 444 U.S. 286, 292 (1980)). Without specifically describing the "minimum requirements" necessary for jurisdiction, even when purposeful availment is found, Justice Brennan did note that "jurisdictional rules may not be employed in sucl a way as to make litigation 'so gravely difficult and inconvenient' that a party unfairly is at a 'severe disadvantage' in comparison to his opponent." Id. at 478 (quoting The Bremen v. Zapata Off-Shore Co., 407 U.S. 1, 18 (1972)); accord McGee, 355 U.S. at 223-24. In sum, Justice Brennan's two-part test suggests that the "rcasonableness" of "other factors" has a substantial impact on the decision whetler to assert jurisdiction once purposeful availment is established. Prior to Asahi, lowever, a majority of the Court had never found that, despite a defendant's purposeful activity in the forum, jurisdiction nonetheless violated International Shoe's minimum requirements of fair play and substantial justice.

77. 107 S. Ct. 1026, 1034 (1987) (emphasis added).

78. Id. at 1037 (Brennan, J., concurring). Despite lis disagreement with the plurality's purposeful availment analysis, Justice Brennan concluded that " $[t]$ his is one of those rare cases in which "minimum requirements inherent in the concept of "fair play and substantial justice" . . defeat the reasonableness of jurisdiction even [thougli] the defendant has purposefully engaged in forum activities." " Id. at 1035 (quoting Burger King, 471 U.S. at 477-78). See infra text accompanying note 80. 


\section{B. The Future of Purposeful Availment.}

The failure of a majority of the Court to resolve the purposeful availment issue was unprecedented in Burger Court due process jurisprudence. Asahi, however, does not presage the diminution of the importance of that concept in the Court's jurisdictional analysis. For the O'Connor Group, purposeful availment remains a sine qua non for the assertion of personal jurisdiction, even im situations where jurisdiction would have been fair in all other respects. ${ }^{79}$ Moreover, the Brennan Group saw the case as a "rare" example of a situation in which purposeful availment was insufficient to confer jurisdiction. ${ }^{80}$ Thus, purposeful availment reinains the most important element in almost all personal jurisdiction cases; the question dividing the Court concerns what constitutes purposeful availment.

The Court's various opinions clarify the views of the Justices on this important issue, first raised but not resolved in World-Wide Volkswagen. Justice White's majority opinion in World-Wide Volkswagen asserted that "[t]he forum State does not exceed its powers under the Due Process Clause if it asserts personal jurisdiction over a corporation that dehivers its products into the stream of commerce with the expectation that they will be purchased by consumers in the forum State." 81 The four members of the O'Connor Group plainly expressed their disagreement with this statement in Asahi; 82 moreover, Justice Stevens indicated that he would limit its application in some cases. ${ }^{83}$ Thus, World-Wide Volkswagen's dictum cannot be said to express the views of the majority of the Court.

The Justices' division over the purposeful availment issue contains an important lesson for those seeking to decode the Court's approach to personal jurisdiction questions. Typically, commentators have combed majority opinions in personal jurisdiction cases for common themes that can be labelled a unitary "doctrine of the Court." 84 A growing body of commentary, however, suggests that this is an inappropriate method for analyzing the course of decisionmaking by the Court. These commentators observe that Supreme Court decisions are the product of the interaction of the approaches taken by nine separate decisionmakers. ${ }^{85}$ If one is

79. $107 \mathrm{~S}$. Ct. at 1033.

80. Id. at 1035 (Brennan, J., concurring).

81. 444 U.S. at $297-98$.

82. $107 \mathrm{~S}$. Ct. at 1033 . See supra notes $59-61$ and accompanying text.

83. $107 \mathrm{~S}$. Ct. at 1038.

84. For examples of such analysis, see generally Stein, supra note 4; Weintraub, supra note 2.

85. See, e.g., Choper, Continued Uncertainty as to the Unconstitutionality of Remedial Racial Classifications: Identifying the Pieces of the Puzzle, 72 Iowa L. REv. 255, $271-74$ (identifying positions of individual Justices on various aflirmative action issues); Easterbrook, Ways of Criticizing the 
to understand the pattern of results, one nuust study each of the nine approaches rather than simply majority opinions.

The pattern of Court decisions fron1 World-Wide Volkswagen to Asahi illustrates this poimt. If one focused only on the unitary doctrine of the Court, one would note only that the Asahi Court faced a question that the World-Wide Volkswagen Court explicitly left open-whether mere insertion of goods into the stream of commerce, with knowledge of their ultimate destination (the forunı state), satisfies the purposeful availment requirement-and that the resolution of the issue remamed uncertain even after the Asahi decision. ${ }^{86}$ A more individualized analysis, on the other hand, would begin by noting that there were three dissenting Justices in World-Wide Volkswagen ${ }^{87}$ and that each of these Justices could be expected to oppose any further narrowing of purposeful availnent. The views of these Justices would prevail in any case in which they could attract two n1ore votes either from nienibers of the original World-Wide Volkswagen majority or from newly appointed Justices who had replaced niembers of that inajority.

In fact, the World-Wide Volkswagen dissenters were able to attract only one additional vote-that of World-Wide Volkswagen's author, Justice White. Justice Stevens, however, abandoned the World-Wide Volkswagen majority to stake out a imiddle position. The result is a Court split three ways over the purposeful availment issue, with each position reflecting a shightly different conception of fairness. All (with the possible exception of Justice Breiman ${ }^{88}$ ) agree on one basic premise-that it is fundamentally unfair to require a person to defend himself before the courts of a sovereign with which he has not voluntarily associated himself. They differ, however, on the degree to whicl1 a defendant nay be charged with comphicity in the actions of others.

The view of the O'Connor Group rests on a highly individualistic vision; members of this group would charge a party with responsibility only for those actions taken by the party itself. Anything less than conduct purposefully directed at the forum state by the defendant-including

Court, 95 HARv. L. REv. 802, 802-03 (1982) (arguing that fragmented opinions are inevitable result of certain structural features of Court's decisionmaking process); Kornhauser \& Sager, Unpacking the Court, 96 YALE L.J. 82, 82-83 (1986) (emphasizing importance of interaction among individual Justices in forming a comprehensive theory of adjudieation); Maltz, The Concept of the Doctrine of the Court in Constitutional Law, 16 GA. L. REv. 357, 369 (1982) (suggesting that "a deeper understanding of the workings of the Court [requires study of] the viewpoints of the individual Justices rather than simply the consensus . . . generated by the imteraction among these viewpoints").

86. See supra notes $81-83$ and accompanying text.

87. See 444 U.S. at 299-313 (Brennan, J., dissenting); id. at 313-17 (Marshall, J., dissenting); id. at 317-19 (Blackmun, J., dissenting).

88. See id. at 306-07 \& nn.11-12 (Brennan, J., dissenting) (jurisdictiou permissible where foreseeable that customer would bring product into distant state). See also infra notes 93-94. 
the mere insertion of its product into the stream of commerce-will not satisfy their definition of purposeful availment. ${ }^{89}$ Members of the Brennan Group are less united in their approach. Justice White split from the other members of the group in both World-Wide Volkswagen and Burger King, ${ }^{90}$ writing the majority opinion in the former and dissenting in the latter. For him the key difference apparently was that Asahi knowingly had placed its product in the stream of commerce via a system of distribution (albeit one not created by Asahi itself) intended to deposit the goods in the forum state, while the defendant in World-Wide Volkswagen had merely sold its product to an ultimate consumer whose unilateral activity brought the goods into the forum state. ${ }^{91}$

Justice Brennan has pursued his own personal jurisdiction analysis, filing separate opinions joined by no other Justice in five of the eleven personal jurisdiction cases clecided in the past decade. ${ }^{92} \mathrm{He}$ would extend broadly the reach of state power in personal jurisdiction cases, focusing on actual inconvenience to defendants and "cominercial reality."93 Indeed, for Justice Brennan, the question of whether goods reach a distant state via a chain of distribution, or by some unilateral act of the customer, is "without constitutional significance, because in [his] view the foreseeability that a custoiner would use a product in a distant State [is] a sufficient basis for jurisdiction." 94 In contrast, in World-Wide Volkswagen Justices Marshall and Blackmun seemed to accept the basic

89. See Asahi, 107 S. Ct. 1026, 1033 (1987). See also supra note 61 and accompanying text.

90. See World-Wide Volkswagen, 444 U.S. at 287-99 (White, J.); Burger King, 471 U.S. 462, 487 (1985) (White, J., joining Stevens, J., dissenting) ("significant element of unfairness in requiring franchisee to defend a case" in forum where franchisee did no busimess and had no reason to believe he would be amenable to suit).

91. See 444 U.S. at 297, 298 (White, J.).

92. See Helicopteros Nacionales de Colombia, S.A. v. Hall, 466 U.S. 408, 419-28 (1984) (Brennan, J., dissenting) (accusing majority of confusing ideas of general jurisdiction and specific jurisdiction and unduly narrowing reach of general jurisdiction); Keeton v. Hustler Magazine, Inc., 465 U.S. 770,782 (1984) (Brennan, J., concurring in the judgment) (downplaying importance of forum state's interests in enforcing its substantive laws and its statute of hitations); Rush v. Savchuk, 444 U.S. 320, 333 (1980) (Brennan, J., dissenting) (incorporating own World-Wide Volkswagen dissent by reference); World-Wide Volkswagen Corp. v. Woodson, 444 U.S. 286, 299-300 (1980) (Brennan, J., dissenting) (blaming Savchuk and World-Wide Volkswagen majorities for "focus[ing] tightly on the existence of contacts between the forun and the defendant [and] . . . accord[ing] too little weight to the strength of the forum State's interest in the case and fail[ing] to explore whether there would be any actual inconvenience to the defendant"); Shaffer v. Heitner, 433 U.S. 186, $219-28$ (1977) (Brennan, $J$., concurring in part and dissenting in part) (decrying majority's "advisory opinion" on the constitutionality of quasi-in-rem jurisdiction under minimum contacts standard, and disagreeing with majority's conclusion).

93. See World-Wide Volkswagen, 444 U.S. at 299-313 (Brennan, J., dissenting).

94. Asahi, 107 S. Ct. at 1037 n.3 (Brennan, J., concurring) (citing World-Wide Volkswagen, 444 U.S. at 306-07 \& nn.11-12 (Brennan, J., dissenting)). Although Justice Brennan's definition of "foreseeability," for purposes of defining purposeful availment, is broader than that expressed by any of his fellow Justices, he would not extend it to "cases involving 'one, isolated occurrence [of consumer 
methodology of the majority, but differed in its application to the case before the Court.95 Although both Justices argued that the reasonableness of foreseeing an autoinobile inanufacturer's or distributor's amenability to suit was a function of the product itself, they both seem to share Justice Brennan's view that for the purposes of determining foreseeability of being haled into a distant foruin, it does not inatter whether the product entered the stream of commerce via a customer's umilateral act or through a distributor's or manufacturer's systein of distribution. ${ }^{96}$ All inembers of the Brennan Group, however, see defendants in Asahi-type cases as links in a chain to which they have voluntarily attached theinselves. ${ }^{97}$ As such, defendants may be charged not only with their own actions, but also with the actions of others in the chain.

Given the present division in Asahi-type cases, the balance of power is held by Justice Stevens. His approach - based on the magnitude of the defendant's penetration of the foruin inarket as ineasured by "the volume, the value, and the hazardous character of the components"98_-is not prefigured by the nuajority opinions in earhier personal jurisdiction cases. Instead, it probably reflects Stevens' idiosyncratic einphasis on the importance of ensuring that the defendant be subject to jurisdiction only where he can be deeined to have had fair notice that he would be subject to suit in the forum. This theme dominated Stevens' separate opinions in both Burger King and Shaffer v. Heitner. ${ }^{99}$

In short, notwithstanding the lack of a majority opinion on the purposeful availment issue, close analysis of the various opinions yields considerable insight into the principles of fairness that generate the Court's approach to this problem.

\section{The Significance of Alienage.}

As discussed above, ${ }^{100}$ the portion of Justice O'Connor's opinion

use, amounting to] . . . the fortuitous circumstance." " $107 \mathrm{~S}$. Ct. at $1037 \mathrm{n.3}$ (quoting World-Wide Volkswagen, 444 U.S. at 295).

95. 444 U.S. at 313-17 (Marshall, J., dissenting) (finding Court's definition of foreseeability too narrow); id. at 317-19 (Blackmun, J., dissenting) (nature of instrunentality nakes expectation of suit in distant state reasonable).

96. Id. at 315 (Marshall, J., dissenting) ("I cannot agree that jurisdiction is necessarily lacking if the product enters the State not through the channels of distribution but $i \mathrm{l}$ the course of its intended use by the cunsumer."); id. at 318-19 (Blackmun, J., dissenting) ("[I]n assessing "nininum contacts,' foreseeable use in another State seenus to me to be hittle different fron foreseeable resale in another State.").

97. Asahi, $107 \mathrm{~S}$. Ct. at 1038.

98. Id. at 1038 (Stevens, J., dissenting).

99. Burger King, 471 U.S. 462, $487-90$ (1985) (Stevens, J., dissenting); Shaffer, 433 U.S. 186, 217-19 (1977) (Stevens, J., concurring in the judgment).

100. See supra notes $65-69$ and accompanying text. 
joined by seven other Justices employs two types of arguments. One type of argument ("domestic arguments") applies to all personal jurisdiction cases. The other type of argument ("international arguments") is limited to questions of jurisdiction over aliens. One of the central questions in Asahi is whether the international arguments were critical to the decision of the Court.

1. Domestic Arguments. If only domestic arguments were considered, reconciling Asahi with prior case law would pose substantial problems. The Court's focus on the fact that no California resident remained a party to the case ${ }^{101}$ is particularly troubling, given its seeming inconsistency with Keeton. As in Asahi, the defendant in Keeton contended that the plaintiff's nonresident status in the forum state underinined the state's interest in adjudicating the dispute, and therefore should have militated against the assertion of jurisdiction. Speaking for eight members of the Court in Keeton, Justice Rehnquist firmly rejected this contention. While conceding that the interest of the state miglit be relevant in some circumstances, Justice Rehnquist concluded that

we have not to date required a plaintiff to have "minimum contacts" with the forum State before permitting that State to assert personal jurisdiction over a nonresident defendant. ...

But plaintiff's residence in the forum State is not a separate requirenent, and lack of residence will not defeat jurisdiction estabhished on the basis of defendant's contacts. ${ }^{102}$

This argument implicitly suggests that state interests should be of limited importance in personal jurisdiction analysis. ${ }^{103}$

The Asahi Court took a different view. While tle action in Keeton clearly derived from "the very activity being conducted, in part, in [the forum state]," 104 Justice O'Connor noted in Asahi that "[t] the transaction on which the imdemnification claim is based took place in Taiwan [because] Asahi's components were shipped from Japan to Taiwan."105 Slie concluded that California liad little interest in adjudicating the controversy. ${ }^{106}$

This contention seems based upon an unduly limited characterization of the situation. Admittedly, the defendant could not liave been liable if it had not shipped the parts; one could equally well say, however,

101. Asahi, 107 S. Ct. at 1034.

102. Keeton v. Hustler Magazine, Inc., 465 U.S. 770, 779-80 (1984).

103. Keeton also suggests that once a defendant's minimum contacts with the forum state have been established, all other concerns-including the interests of the forum in the outcome of the case-are of secondary importance. See supra text following note 36 .

104. 465 U.S. at 780.

105. $107 \mathrm{~S}$. Ct. at 1034.

106. Id. 
that Asahi would not have been hable if there had been no accident-an occurrence that took place in the foruin state. Viewed froin this perspective, California's connection with the action seens much more substantial.

The problein is exacerbated by the Court's rehance on the fact that the original dispute between Cheng Shin and the inotorcycle driver had been settled-a circumstance which the Court argued deprived California of its prinary contact with and interest in the case. ${ }^{107}$ This emphasis seeins flatly inconsistent with Keeton and other recent case law in which the focus has been on fairness to the defendant. ${ }^{108}$ Asahi simply does not care whether a Cahifornia plaintiff is or is not a party to the case; the substantive character of its defenses and the inconvenience of defending in California are unaffected by the settlement. By focusing on the lack of state interest, the Court seems to be returning to the personal jurisdiction analysis used in pre-World-Wide Volkswagen cases, such as Kulko v. Superior Court of California ${ }^{109}$ and Shaffer v. Heitner. ${ }^{110}$

These seeming inconsistencies with prior case law might be explained by asserting that some Justices had changed their positions on the relevant criteria for determining personal jurisdiction. If one were dealing with changes in the votes of one or two Justices, such an explanation might be plausible. It is less probable when, as in Asahi and Keeton, seven Justices joined seemingly inconsistent opinions. ${ }^{111}$ In such a case, it seems likely that other factors explain the result. The distinguishing factor in Asahi was that the defendant was an alien, rather than a citizen of the United States. In assessing the opinion of the Court, the international factors thus provide the inost appropriate focus for analysis.

2. International Arguments. Limiting the significance of Asahi to the special problems raised by the assertion of jurisdiction over aliens avoids direct conflict with establisled principles of due process analysis. At the same time, however, such an approach writes a new cliapter in the stormy relationship between the concept of federalisin and the analysis of jurisdictional problenns. The possibility that federalism concerns niay be a factor in the personal jurisdiction calculus was first suggested in Justice White's majority opinion in World-Wide Volkswagen:

[W] have never accepted the proposition that state lines are irrelevant for jurisdictional purposes, nor could we, and remain faithful to the

107. Id.

108. See, e.g., Keeton, 465 U.S. at 779-81.

109. 436 U.S. 84, 98-101 (1978).

110. 433 U.S. $186,214-15$ (1977).

111. Chief (then Associate) Justice Rehnquist, Justices White, Marshall, Blackmun, Powell, Stevens and $\mathrm{O}^{\prime}$ Connor voted together in Keeton and in the relevant portion of Asahi. 
principles of interstate federalism embodied in the Constitution. . . . [T] he Framers . . . intended that the States retam many essential attributes of sovereignty, including, in particular, the sovereign power to try causes in their courts. The sovereignty of each State, in turn, implied a limitation on the sovereignty of all of its sister States-a limitation express or implicit im both the original scheme of the Constitution and the Fourteenth Amendment. ...

....

... Even if the defendant would suffer minimal or no inconvenience from being forced to litigate before the tribunals of another State; even if the forum State has a strong interest in applying its law to the controversy; even if the forum State is the most convenient location for litigation, the Due Process Clause, acting as an instrument of interstate federalism, may sometimes act to divest the State of its power to render a valid judginent. ${ }^{112}$

This language generated a flurry of scholarly criticism. ${ }^{113}$ Much of the criticism pointed out that a personal jurisdiction analysis relying on the concept of states' rights was inconsistent with the notion that defendants could waive their objections to personal jurisdiction. For while private defendants should be in a position to waive their own rights, they should hardly be given the power to forfeit the sovereign prerogatives of state governments. Thus, if considerations of federahsm were in fact at the core of the fourteenth alnendment limitations on jurisdiction, all such limitations should be treated as nonwaivable constramts on subject matter jurisdiction. A majority of the Justices soon recognized this problem; in Insurance Corporation of Ireland v. Compagnie des Bauxites de Guinee, ${ }^{114}$ the Court abandoned the notion that considerations of federalism were central to personal jurisdiction analysis.

Asahi implicitly confirms the demise of the federahsm analysis used in World-Wide Volkswagen. Obviously, states are under no constitutional obligation to preserve the sovereign status of foreign nations; therefore, the considerations of federalism raised in World-Wide Volkswagen are irrelevant to the relationship between a state and a foreign citizen. Thus, if federalism-based concerns were an important part of the

112. 444 U.S. at 293-94 (citing Hanson v. Denckla, 357 U.S. 235, 251, 254 (1958)).

113. See, e.g., Redish, Due Process, Federalism, and Personal Jurisdiction: $A$ Theoretical Evaluation, 75 Nw. U.L. REv. 1112, 1120 (1981) ("The terms of the fourteenth amendment's due process clause refer to the rights of 'persons,' not states. ... Yet, without any supporting reference to the language, policy, or history of the fourteenth amendment or to the general concept of due process, the Supreme Court has consistently appended considerations of federalism to its due process analysis of personal jurisdiction."); Weinberg, supra note 2, at 924 ("State sovereignty seems a priori to have nothing to do with due process and is not mentioned in the due process clause.").

114. 456 U.S. 694, $702-03$ n.10 (1982) (restriction on state sovereign power "ultimately a function of the individual liberty interest preserved by the Due Process Clause" rather than a function of federalism concerns); see also Phillips Petroleum Co. v. Shutts, 472 U.S. 797, 807 (1985); Burger King, 471 U.S. 462, 472 n.13 (1985). 
justification for jurisdictional limitations, one would expect that aliens would receive less protection from the due process clause. Asahi is clearly mconsistent with this conclusion.

Indeed, Asahi suggests that considerations of federalism play an entirely different role than that suggested by World-Wide Volkswagen; rather than contributing to constraints on a state's authority to exercise personal jurisdiction, such considerations actually reduce these constraints in some circuinstances. In this context the reference to values of federalism is not, as suggested by World-Wide Volkswagen, related to the preservation of state sovereignty. Instead, Justice O'Connor's analysis reflects two otlier types of federalism-related concerns.

First, Justice O'Connor's reference to potential problems of foreign relations generally implicates vertical federalism-the interaction between the national government and the state governments. ${ }^{115}$ She correctly observed that the federal government is cliarged with regulating relationships with foreigu nations, and that excessive assertions of jurisdiction by states can create tensions between these nations and the United States, thereby making the federal task of managing these relationslips more difficult. By limiting state court jurisdiction over foreign citizens, the possibility of creating tensions is thereby limited.116

In less obvious ways, the opimion of the Court also implicates the concept of horizontal federalism-the principles that govern the relationship among the different states of the umion. Admittedly, only one state-Califorina-is involved in Asahi. But by focusing on "special" burdens imposed on foreign defendants, ${ }^{117}$ the Court implicitly suggests that horizontal federalism has an influence on the outcome of domestic jurisdictional challenges. In the absence of the federal structure created by the Constitution, a defendant from state $A$ could claim that he was subject to the same burdens as a foreigu citizen if he was summoned to defend a suit in state $B$. Within this strncture, lowever, a citizen of one state is not entitled to consider the system of another state "foreign" in the same sense that he might use that tern to describe the system of anotler nation. Thus, because of the nature of federalism, a domestic defendant is more likely than a foreigu defendant to be subject to suit in a state that is not his lome.

This argument relates to the most basic theme of personal jurisdiction analysis. The fundamental question in the jurisdiction cases has always been whether the defendant has sufficient contacts with the forum

115. $107 \mathrm{~S}$. Ct. at 1034-35.

116. Born, supra note 43 , at $27-34$.

117. $107 \mathrm{~S}$. Ct. at 1034 . 
to render the assertion of jurisdiction "fair."118 A citizen of state $A$ is already indirectly connected to state $B$ through the structure of the federal system; in contrast, a citizen of a foreign country has no such automatic connection. Therefore, as Asahi suggests, a greater volume of additional connections is required to justify the exercise of jurisdiction over the citizen of a foreign nation. In short, federahism-related values become elements in the calculus of fairness to the defendant which determines the outcome of challenges to state assertions of personal jurisdiction.

\section{CONCLUSION}

Asahi does not presage a major change in the direction of the jurisprudence of personal jurisdiction. Admittedly, the discussions of minimum contacts, purposeful availment and the significance of American citizenship are important theoretically; in practice, however, they shed new light only on marginal cases. Thus, any changes in doctrine generated by the case are best viewed as increinental rather than seminal.

The primary message which ennerges from Asahi is that in close cases personal jurisdiction decisions will often defy easy characterization. Such decisions are likely to reflect a coinplex interaction among a variety of different values rather than the straightforward apphication of a small number of principles. Two factors explain this phenomenon. First, the majorities in such cases inay be coalitions of Justices with varying approaches to personal jurisdiction analysis. Second, the individual views of each Justice may very well reflect the influence of a variety of different factors.

Admittedly, this complexity makes the construction of academic models which fully explain the pattern of decisions somewhat difficult. The task is made even inore difficult by changes in the inake-up of the Court that can be decisive in close cases. ${ }^{119}$ Given this complexity, it is easy to characterize the actions of the Court as totally irrational or internally inconsistent. But complexity is not irrationahity; indeed, commentators fail in one of their primary inissions if they do not take the time and effort necessary to understand fully judicial decisions and the values which underlie them. For only after accurately identifying the values

118. See International Shoe Co. v. Washington, 326 U.S. 310, 316-20 (1945).

119. Newly appointed Justice Anthony Kennedy has yet to rule on a personal jurisdiction case as a member of the Supreme Court. As an appellate judge on the United States Court of Appeals for the Ninth Circuit, then-Judge Kennedy in at least one instance joined the opinion of a three-judge panel that followed a restrictive definition of purposeful availment. See Pacific Trading Co. v. M/V Main Express, 758 F.2d 1325 (1985) (Nelson, J.). It is remains to be seen whether Kennedy will take a similar position on the Supreme Court. 
which inform the Court's approach to personal jurisdiction analysis can one devise a truly effective critique of that approach. As the foregoing analysis of Asahi dennonstrates, the task of the commentators in this regard is difficult, but not impossible. 